\title{
Sources of Transparency: Information Systems in International Regimes
}

\author{
Ronald B. Mitchell \\ University of Oregon
}

\begin{abstract}
Scholars and practitioners alike have stressed the important role of transparency in promoting international regime compliance and effectiveness. Yet many regimes fail to create high levels of transparency: governments and nongovernmental actors regularly fail to monitor or report on their own behavior, the behavior of other actors, or the state of the problem these regimes seek to resolve. If more transparency often, if not always, contributes to regime effectiveness, then identifying the sources of transparency becomes an important research task. Regime transparency depends upon both the demand for information and the supply of information. Specifically, regimes can seek "effectiveness-oriented" information to assess whether regime members are collectively achieving regime goals or "compliance-oriented" information to assess whether particular actors are individually fulfilling regime commitments. The incentives and capacities that relevant actors-whether governments, nongovernmental organizations, or corporate actors-have to provide such information depend on whether the regime's information system is structured around self-reporting, other-reporting, or problem-reporting. Although many of these factors are determined by characteristics of the actors involved or the structure of the problem, regimes can increase transparency by enhancing the incentives and capacity actors have to contribute to a particular regime's transparency.
\end{abstract}

Transparency is crucial to the effectiveness of international regimes. Indeed, promoting transparency-fostering the acquisition, analysis, and dissemination of regular, prompt, and accurate regime-relevant information-is often one of the most important functions regimes perform. In many regimes, such information underpins efforts to alter state behavior and allows regime members to evaluate past progress in order to redesign the regime to perform better in the future. Yet, for all its nominal importance to regime success, many regimes fail to induce adequate transparency. Both anecdotal incidents-from Iraqi nuclear programs to years of clandestine Soviet whaling-and more systematic evaluations remind us that governments regularly fail to provide the timely and accurate reports mandated by most security, human rights, and environmental treaties. Nor do governments usually

Author's note: The Graduate School of the University of Oregon generously supported this research through a Faculty Summer Research Fellowship. The author would like to thank Robert Darst, Susan Subak, and three generous anonymous reviewers who provided comments and advice that vastly improved the article. An earlier version of this paper was presented as "A Taxonomy of Transparency: Compliance Information Systems in International Environmental Agreements" at the International Studies Association Conference held in Chicago in February 1995. 
allow international organizations or other actors to collect independent information on treaty-relevant behavior. Even regime secretariats that have information often fail to analyze or disseminate it in ways that facilitate regime goals. In short, the necessity for transparency has not been the mother of its invention.

Practical and theoretical understanding of how a regime can create or increase transparency remains rudimentary. Although "many literatures discuss transparency or touch on topics related to transparency" (Lindley, 1996:4), few scholars have made transparency the focus of study. Such literature as does exist has focused on evaluating transparency as a determinant of regime success and has been largely deductive, relying on theoretical rather than empirical support for the alleged relationship. ${ }^{1}$ Almost no work to date has investigated the determinants of transparency.

Although the question of whether and when transparency fosters regime effectiveness surely deserves study, this article assumes that under many conditions, and ceteris paribus, increasing transparency will not decrease-and may increase-regime effectiveness. ${ }^{2}$ Given this, I identify and analyze the determinants of the transparency deemed so important to regime attempts to alter behavior and solve international problems (Young, 1991; Levy, Young, and Zürn, 1995). A regime's transparency depends on the purposes for which the regime seeks information, that is, the demand for information; the incentives and capacity of relevant actors to provide that information, that is, the supply of information; and the strategies the regime adopts to increase transparency. Given the dearth of previous theorizing regarding the sources of transparency, this article generates a deductive framework for understanding these three influences. I illustrate the argument with examples drawn from security, trade, environment, and human rights regimes. These examples are not intended to test hypotheses using rigorous quantitative analysis or case studies, but rather to lend empirical plausibility to the framework developed.

\section{Transparency: Important, Elusive, and Poorly Understood}

Transparency as used here refers to the availability of regime-relevant information. Although transparency also includes the "openness" of a government's political system and decision-making procedures to external observers, I focus in this article on a narrower conception of transparency as information regarding the operation and impact of a regime. Transparency varies in degree across regimes, within regimes, and over time: some regimes will be more transparent than others; a single regime will be more transparent in certain respects than in others; and regimes will be more transparent during certain periods than others. Transparency is manipulable via the regime's information system-the actors, rules, and processes by which the regime collects, analyzes, and disseminates information (Mitchell, 1994:53). The information systems consist of "inputs" related to reporting on, monitoring, and verifying behavior and the state of the environment as well as "outputs" related to aggregating, processing, evaluating, publicizing, and responding to this information.

\footnotetext{
${ }^{1}$ See, for example, Chayes and Chayes, 1995. Exceptions include two political science graduate students currently completing their Ph.D. dissertations on transparency in security regimes-Dan Lindley at MIT and Jim Marquardt at the University of Chicago-and a large international project based at the International Institute for Applied Systems Analysis that looked at review mechanisms in environmental treaties as a source of transparency and as an influence on the behavior of parties under those treaties (Victor, 1994).

2 See Downs, Rocke, and Barsoom, 1996, for a critique of the argument that transparency by itself will increase compliance.
} 
International relations scholars, especially regime theorists, have consistently touted the virtues of transparency as a source of regime effectiveness. ${ }^{3}$ To effectively alter the behavior of states and substate actors, regimes (or the states that compose them $)^{4}$ must either have-or create-information about the activities they seek to regulate and the impact of those activities on the ultimate goals of the regime. The reciprocity that underlies tit-for-tat strategies, for example, hinges on the ability to "distinguish reliably between cooperation and defection" (Oye, 1996:15). Arms control theory is replete with references to transparency, verification, monitoring, reporting, data exchange, and surveillance as crucial prerequisites to the success of any accord. The GATT's Trade Policy Review Mechanism serves to encourage more liberal trade policies as well as to clarify existing policies (Qureshi, 1990). Analysts consider the reporting and review procedures common to human rights and labor agreements as crucial to their success (Alston, 1992; Landy, 1966). Many environmental regimes collect information both on the regulated behaviors and on the state of the environment itself. In these cases, transparency facilitates coordinated action by regime supporters, reassures those concerned about being "suckered" for complying, and provides the informational basis for treaty revision (Sachariew, 1991:32-3). Even those skeptical of current trends in regime theory note transparency's importance as the primer for the sanction pump (Downs, Rocke, and Barsoom, 1996:393). Transparency facilitates compliance, effectiveness, and the ability to assess both (Sands, 1993:372; Young, 1991:176). In short, transparency provides the foundation for a regime to "do well" as well as to "know how well it is doing."

Like theorists, practitioners also stress the value of transparency. The increasing time, energy, and paper dedicated to verification issues testifies to the importance policy makers place on transparency in the arms control context (Chayes and Chayes, 1995; Abbott, 1993). The International Labor Organization (ILO) conducts periodic reviews of all countries' implementation of the conventions it oversees (O'Flaherty, 1994). Environmental treaties collect information from member governments but also from nongovernmental organizations (NGOs), private corporations and individuals, scientific research teams, other international organizations, and on-site inspections (Fischer, 1991; Sand, 1992:12-4). In the case of climate change, many analysts proposed that governments develop transparent information systems even before negotiation of the United Nations Framework Convention on Climate Change (FCCC) had been completed (Chayes, 1991; Lang, 1991:173).

Transparency's value is reaffirmed by the criticism of regimes that lack strong information systems as weak and ineffective and the ongoing efforts of regimes to improve such systems over time (Kimball, 1992:45). Considerable efforts have gone into refining and improving human rights reporting systems (Alston, 1992). Signing of the FCCC was immediately followed by calls from the Organisation for Economic Co-operation and Development (OECD) and others for creation of a "complete, comparable and transparent" reporting system (cited in Kim, 1994:21). The Convention on Long-Range Transboundary Air Pollution (LRTAP) recently adopted "a more detailed, transparent and revealing national reporting system [and] a detailed mechanism for monitoring national compliance" (UN/ECE, 1994:133).

Despite the importance attached to transparency, it remains elusive in practice. Environmental, human rights, and security regimes regularly fail to produce prompt, high-quality, accurate information on the behaviors and problems they

\footnotetext{
${ }^{3}$ An excellent, extended treatment of issues related to transparency is available in chapters 6 through 8 of Chayes and Chayes, 1995.

${ }^{4}$ In this article, I refer to regimes as if they were purposive actors in their own right. Although I hope this improves the flow of the prose, it should be understood that in such cases I am referring to regime members collectively or the secretariat/executive body.
} 
seek to remedy (Chayes and Chayes, 1995:155-62). Governments regularly ignore simple and nonintrusive reporting requirements (General Accounting Office, 1992a). The continuing dearth of government reports under the Montreal Protocol on ozone depletion, the London Dumping Convention, the International Convention for the Protection of the Sea from Ships (MARPOL), and the Convention on International Trade in Endangered Species (CITES) illustrates that even high visibility and well-established regimes experience such problems (UNEP/ OzL.Pro.4/6, 1992:3; IMO/LC.2/Circ.318, 1993:1; Peet, 1992; Trexler, 1989). Even the highly interdependent European Union often receives late and inadequate mandatory environmental reports (Collins and Earnshaw, 1993:231). Data that secretariats do receive is often incomplete or inaccurate (Trexler, 1989; Yablokov, 1994).

Fortunately, the record is not universally poor. Reporting rates under most human rights treaties have been consistently high for years (Alston, 1992; Landy, 1966). The LRTAP Convention receives regular government reports and combines these with independent data on fossil fuel use to estimate transboundary acid precipitation fluxes (Levy, 1993). Fifteen of eighteen countries required to turn in initial emissions inventories under the FCCC did so within a month of the required date (Subak, 1995:20). European states regularly provide high-quality enforcement data to a regional maritime regime even while failing to provide the same information to the global maritime regime (Mitchell, 1994:135-6). Whaling countries have regularly reported to the International Whaling Commission (IWC) (General Accounting Office, 1992a:26).

If structural features of the international system made transparency impossible for a regime to achieve, that is, if factors produced "a uniformity of outcomes despite the variety of inputs," we would not observe such variation in transparency (Waltz, 1979:73). This empirical variation suggests that transparency is influenced by features of an issue area and/or features of the regime information system itself, that is, by exogenous and endogenous sources. Yet research to date has not focused on these issues. Extant theorizing has approached transparency as an independent variable, focusing on "the question of how transparency ... operates to enhance compliance with treaty norms" (Chayes and Chayes, 1995:135; Lindley, 1996:31; Florini, 1995). Arms control, human rights, and environmental researchers have described the lack of reporting and transparency, analyzed how transparency influences compliance and effectiveness, or prescribed the information systems regimes should adopt to increase effectiveness (General Accounting Office, 1992a; Mueller, 1994; Tietenberg and Victor, 1994:27; Greene, 1994; Katscher, Stein, Lanchbery, and Salt, 1994). Assuming these scholars are correct that transparency really does - at least sometimes-increase regime effectiveness, then an equally important question must be what factors increase regime transparency. The framework here, therefore, takes transparency as the dependent variable, and looks at why some regimes achieve greater transparency than others.

Before proceeding, three caveats are in order. First, although enhancing transparency often facilitates regime goals, opacity also has its virtues. Too much transparency may inhibit cooperation. International negotiations often require diplomatic secrecy, as evidenced with the Israeli-Egyptian Camp David accords or the Norwegian brokering of the Israeli-Palestinian peace accords. Reducing the uncertainty and increasing transparency about the regional impacts-and "winners" and "losers" - of climate change may make reaching multilateral agreement to combat climate change more difficult. Certain types of information exchange will not occur at all unless the provider is assured that the recipient will prevent or severely limit subsequent dissemination of the information. Maintaining a flow of information often requires maintaining tight control over "who can have what information when." A regime may be able to increase the deterrent effect of 
sanctions by controlling information to make them appear larger and more likely than they actually are. Second, negotiators also need to trade off the benefits of transparency against other regime objectives. Most superpower arms control agreements signed during the Cold War (and whatever benefits they provided) could not have been achieved had the United States insisted on greater levels of transparency. And once the Russians accepted more intrusive inspection procedures, American diplomats had to weigh the security benefits from better inspections against the economic risks of corporate espionage. In short, the benefits of increasing a regime's transparency must be weighed against its costs and traded off against other regime goals. Third, the type of states involved in a regime may influence the ability of the regime to create transparency. Regimes composed largely of liberal democracies will probably achieve greater transparency simply because of the generally more open information flow within such societies. Indeed, most of the examples developed below involve regimes dominated by liberal democracies. We might presume that more authoritarian governments know and will reveal less about their citizens while their citizens know and will reveal less about their governments, creating institutional obstacles to regime transparency. These points made, however, transparency nonetheless frequently appears to be worth pursuing but difficult to create even in regimes populated primarily by open societies.

This section has documented three points. First, theorists and practitioners contend that transparency is crucial to regime effectiveness. Second, creating transparency is no easy feat and many regimes fail to create high levels of transparency. Third, analysts have not yet studied or identified the factors that influence the supply of transparency for which regimes clearly have a high demand. In short, transparency is important to regime effectiveness, difficult to achieve, and its sources are poorly understood.

\section{The Demand for Information}

Regimes collect information either to evaluate the performance of the regime or to evaluate the performance of individual parties to the regime. ${ }^{5}$ Effectivenessoriented transparency focuses on the question, "how well are we collectively doing at achieving regime goals?" Compliance-oriented transparency focuses on the question, "how well are particular actors doing at fulfilling regime commitments?" The key distinction between these two types of transparency lies not in the content of the information collected but in the uses to which that information is put. Regimes can gather information on legislation passed, regulations promulgated, compliance and enforcement activities, other regime-related behaviors, or the state of the problem. In an effectiveness-oriented model of transparency, this information feeds a process by which regime members and other recipients of the information can (a) assess progress to date in managing the problem and (b) identify directions for revision and renegotiation of the regime to do better in the future. In a complianceoriented model, the regime uses this information to induce some response to those national or subnational actors identified as failing to fulfill regime requirements. These responses often entail sanctioning deviant behavior but may include rewarding good behavior, educating actors, or other responses (Mitchell, 1996). Political dynamics in many regimes, however, create sufficient obstacles to such responses that many regimes end up with fundamentally effectiveness-oriented information systems. Even regimes that nominally seek compliance-oriented information often use the information in ways that facilitate evaluation but stymie efforts at response.

\footnotetext{
5 These categories parallel Levy, Young, and Zürn's (1995) conception that regimes can be evaluated with respect to both their behavior-changing and problem-solving effectiveness (see also Andresen and Wettestad, 1995).
} 
Environmental regimes pose particularly interesting informational problems because they seek to alter human behavior as an instrumental means to averting changes to the natural environment (Sachariew, 1991). In nonenvironmental treaties, a direct, exclusive, causal relationship usually exists between the regulated behavior and the problem the regime seeks to resolve. For such regimes, the ultimate goal is to ensure that proscriptions on weapons procurement, tariff rates, or torture are not breached. Therefore, information on those behaviors can provide direct and compelling evidence that arms control, trade, or human rights goals have been achieved. In contrast, environmental regimes seek to reverse negative trends in the quality and quantity of various environmental resources. Yet, even though information about violations of international pollution or wildlife laws rarely provides reliable evidence on environmental trends, most such regimes do not require governments to monitor environmental quality (Kimball, 1992:45). A sample of thirteen environmental treaties revealed requirements for reporting on behavior in all thirteen but for measuring environmental trends in only four (Fischer, 1992:48). Nonetheless, most environmental regimes tend to use even the information they collect on behavior in an effectiveness-oriented mode.

Effectiveness-oriented systems usually pose less challenging political obstacles and less demanding resource requirements than those faced by compliance-oriented systems. The goal of evaluating regime members' collective effort, or the effects of that collective effort, reduces both the requirements of and constraints on the information system. The regime need only gather information on a representative fraction of the relevant behaviors or problems to extrapolate regarding the regime as a whole. Information need not be comprehensive nor complete with respect to all aspects of the problem, all actors involved, or all time periods. Information can be compiled from various sources and can be aggregated across actors and even across data types. The content of reports and the data gathered need not be especially detailed or even correspond exactly to the most desirable indicators of regime performance. Indeed, information gathered need bear little relationship to the behavioral proscriptions and prescriptions of the regime, so long as the information correlates reasonably well with the regime's definition of "success." Information need not be "verified" in any strict sense, since all available data will be used collectively to come to general determinations about past progress and future directions. In short, a wide variety of information, from different sources, of different types, at different levels of detail can be used to "triangulate" on how well the regime is doing. Of course, better quality data will produce a better estimate of how well the regime is actually doing. But the goals of evaluating the regime and identifying directions for future effort can often be achieved adequately (even if not perfectly) with information that meets only minimal standards for quality and quantity.

In contrast, political exigencies impose demanding standards on regimes seeking to use information as the basis for a response to induce behavioral change by one or more specific regime members. Systems to promote negative responses such as sanctioning of noncompliant states or nonstate actors face extremely demanding informational requirements. If sanctions are likely, those engaged in undesirable behavior will have few incentives to supply accurate information themselves and strong incentives to prevent others from supplying such information. Information collected must correspond precisely to the behavioral definitions of the regime. The regime's rules will need to distinguish clearly between desirable and undesirable behavior, that is, between compliance or noncompliance, and information must be such that it allows such classification in the case at hand. Information collected must then be verified to minimize false accusations. Indeed, the American reluctance to accuse the Soviets of arms control violations during the 1980s illustrates the diplomatic deference that-even when evidence of wrong-doing is clear-produces 
"standards of evidence" that may exceed even those of domestic courtrooms. Even within regimes that meet these requirements, sanctioning remains rare (DeSombre, 1995; Hufbauer and Schott, 1985). ${ }^{6}$

These obstacles to transparency in such negative response systems find parallel, if not quite as large, obstacles in response systems that attempt to promote desirable behavior by providing incentives or additional resources to increase the capacity to fulfill obligations. Regime members will resist financial or technology transfers unless the regime generates clear evidence that the actor's nonconforming behavior was driven by incapacity not intention. Like a college student applying for financial aid, a developing country looking for assistance to meet its international commitments must make considerable information available to donor states and regimes. Equally important, the applicant for assistance usually must allow the secretariat or other states to independently verify such information and provide ongoing access to relevant information. Structural adjustment loans provided by development banks as well as the incremental compliance costs offered under recent environmental agreements require that regimes collect and process large quantities of information as a prerequisite to providing such rewards and capacity enhancements.

Anecdotal evidence supports a prediction that the more demanding requirements of compliance-oriented information systems will make them less common than effectiveness-oriented systems. In many agreements, the information collected allows evaluation of the regime's overall success but lacks the detail needed to identify whether specific actors are fulfilling regime provisions. Some regimes have clear goals but no specific proscriptive or prescriptive standards to measure behavior against. The FCCC, for example, requires governments to provide "a national inventory of anthropogenic emissions by sources and removals by sinks of all greenhouse gases" but not to actually regulate such emissions (United Nations, 1992:Art. 12). Other regimes have clear behavioral standards but establish reporting formats that simply do not request the information needed to assess whether a state is in compliance. Regimes regularly appear only minimally attentive to issues of compliance and violation, either to avoid the political difficulties of directly addressing compliance or to focus attention on effectiveness.

In part, this focus on evaluation rather than response may simply make a virtue of necessity. States and nonstate actors often will provide only aggregate data that allow evaluation of regime effectiveness, fulfill requirements regarding information provision, but prevent potential sanctions for nonfulfillment of obligations. The European Union fought for the right to provide aggregate, rather than state-level, climate change emission data under the FCCC (Bodansky, 1993). In marine pollution and stratospheric ozone negotiations, corporations only provide data aggregated in ways that protects the anonymity and proprietary rights of individual corporations. The secretariat for the regime for European enforcement of maritime regulations collects state-specific data but publishes only collective data in response to the desire of member states to preclude the negative publicity of being identified as not meeting enforcement goals (Secretariat of the Memorandum of Understanding, 1992; Huibers, 1991). This last case demonstrates that even regimes that have information that would allow some response strategy often use it simply to evaluate regime effectiveness.

Although we should expect effectiveness-oriented transparency to be more common than compliance-oriented transparency, we should also expect pressures for the latter to grow as a regime matures. Initially, information on statutes and regulations or on the status of a given problem serves the valuable function of

\footnotetext{
${ }^{6}$ Downs, Rocke, and Barsoom (1996) argue that the rarity of enforcement is driven by the "shallowness" of cooperation.
} 
indicating the level of states' commitment to regime goals. Passing new legislation and regulations, for example, to protect political or workers' rights or the environment, introduces regime goals into the domestic policy context. Indeed, such actions may be the only available indicators that a government is making efforts to overcome the governmental and bureaucratic inertia that plagues even committed supporters of the regime. Aggressive regimes addressing as yet poorly understood problems may adopt effectiveness-oriented information systems simply to understand the current state, future trends, and likely causes of a problem. Over time, however, regime members and the secretariat will want evidence that real behavioral change is taking place and producing a real impact on the problem. Initially, indications of legislative and regulatory changes can satisfy the political demand for evidence that the regime has "made a difference," but evidence of more substantial behavioral changes soon becomes necessary to satisfy that demand.

\section{The Supply of Information}

If the demand for information is driven by the two different functions the information can serve, the supply of information depends upon the interaction between what information the regime demands and from whom the regime demands it. In any given regime, the interaction between "content" and "source" creates three types of information: information provided by an actor on its own behaviors, or "self-reporting"; information provided by an actor on other actors' behaviors, or "other-reporting"; and information provided on the effects of behaviors and other nonbehavioral aspects of the problem itself, or "problem-reporting." Although most regimes rely on self-reporting by governments because it is more politically palatable and cheaper than other means of creating transparency, some regimes collect information from nongovernmental organizations, corporate actors, individuals, or other intergovernmental agencies (Tietenberg and Victor, 1994:31; Birnie and Boyle, 1992:166; Ausubel and Victor, 1992:17).

The categories of self-, other-, and problem-reporting capture the ways in which variation in incentives and capacities will influence variation in the level of transparency. The incentives to provide information that determine why one regime exhibits greater transparency than another can be found in the answers to two basic questions: "Information from whom?" and "Information about what?" For self-reporting, the incentives to provide information depend on the actor's support for regime norms and the conformance of their behavior to those norms. For other-reporting, the incentives depend on the actor's support for regime norms and the impact nonconformance with regime norms by others has on their interests. For problem-reporting, the incentives depend almost exclusively on the actor's support for regime norms. The capacity of actors to provide such information also influences transparency. In particular, such capacity will depend on characteristics of the information being requested and on characteristics of the actor providing that information.

\section{Self-Reporting}

In their simultaneous roles as creators and primary subjects of international law, governments recognize the importance of transparency to regime influence but are wary of providing foreign governments or nonstate actors with rights that would reduce or infringe existing sovereign control over information. Therefore, governments usually establish regime information systems that rely primarily, if not exclusively, on government self-reporting regarding their own territory and citizenry (Chayes and Chayes, 1995). In other cases, governments serve as conduits for information from substate actors reporting on their own compliance, as in industry 
reports on chlorofluorocarbon production under the Montreal Protocol. Such systems seek information from actors who usually have the capacity to provide it but may not have the incentives to do so. In this context, an actor's support of regime norms and the conformance of their behavior with those norms create cross-cutting pressures between the actor's incentives as a regulatory target of the regime and as a potential contributor of information to the regime. Thus, a regime faces some mix of the four types of actors depicted in Figure 1: committed conformers, good faith nonconformers, coincidental conformers, and intentional violators.

\begin{tabular}{|c|c|c|}
\hline & $\begin{array}{c}\text { Supportive of Regime } \\
\text { Norms }\end{array}$ & $\begin{array}{c}\text { Opposed to Regime } \\
\text { Norms }\end{array}$ \\
\hline $\begin{array}{c}\text { Behavior Conforms with } \\
\text { Regime Norms }\end{array}$ & $\begin{array}{c}\text { Committed } \\
\text { Conformer }\end{array}$ & $\begin{array}{c}\text { Coincidental } \\
\text { Conformer }\end{array}$ \\
\hline $\begin{array}{c}\text { Behavior Fails to } \\
\text { Conform with Regime } \\
\text { Norms }\end{array}$ & $\begin{array}{c}\text { Good Faith } \\
\text { Nonconformer }\end{array}$ & $\begin{array}{c}\text { Intentional } \\
\text { Violator }\end{array}$ \\
\hline
\end{tabular}

FIG. 1. Actor types for self-reporting.

"Committed conformers," through self-reporting, can simultaneously facilitate the collective goal of regime progress and the individual goal of improved public image. For example, in regimes regulating international trade, self-reporting by governments that are rigorously enforcing drug, customs, endangered species, or tropical timber trade regulations allows them to increase the deterrent effect of their enforcement while improving the perception that their country is a "member in good standing" of the regime. The use of self-reporting to challenge other states to do better can be seen in contributions to the International Union for the Conservation of Nature's database on endangered species legislation and in the "tote-board diplomacy" of European acid rain regulation (Levy, 1993). For governments, the regime provides a forum for policy dissemination. For both governments and nonstate actors, the regime provides a forum to reap additional political benefits for efforts already made.

"Good faith noncomformers"-regime supporters whose behavior falls short of regime norms because of incapacity or inadvertence-also may see reporting as reaffirming their commitment to regime goals. For years, European state members of a marine enforcement regime have provided the secretariat with almost daily, detailed data on ship inspections even though almost none of them "have ever met the required 25 percent inspection rate"(Mitchell, 1994:136). The international wetlands regime assumes governments want to protect their wetlands even when they fail to do so, offering advice and assistance whenever wetlands degradation is reported (Ramsar Convention Bureau, 1990). Governments and corporations that are supportive will have incentives against reporting, however, if they fear that revealing episodes of nonconformance will lead to sanctions, either by the regime or by a more amorphous "public."

"Coincidental conformers"- -actors indifferent or opposed to regime norms but whose behavior conforms to those norms for reasons other than regime commitment-have incentives to selectively self-report if the regime offers sufficient political rewards. Although opposed to regime norms, such actors will self-report behaviors that match regime norms if doing so provides instrumental benefits. This 
will be especially likely if they believe their opposition is unlikely to change regime norms. For example, a government whose laws meet regime standards-whether their practice does or not-can promote their public image by fulfilling regime requirements to report on those statutes (Haas, 1993). Of course, countries rarely formalize policies authorizing torture or environmental degradation and so such reporting reveals little about the state's true policy priorities. Similarly, reductions in power production in the Soviet Union and Russia due to the economic downturn of the 1980s and early 1990s placed them in compliance with LRTAP's requirement for 30 percent reductions in European sulfur dioxide fluxes; reporting such facts provides a way to generate public relations benefits. Such actors have incentives to claim they are fulfilling regime norms, even while downplaying that they are doing it for independent social, political, or economic reasons.

"Intentional violators" are least likely to self-report honestly. Free-riders will fail to self-report or will provide false self-reports so that they can reap the benefits of international cooperation by other states, without contributing to that effort (Stein, 1983:129-30; Krasner, 1991). Actors who explicitly reject regime norms will refuse to even report, as one of many efforts to undermine regime norms and progress. In the many regimes that exhibit such low reporting rates that nonreporting does not indicate noncompliance, intentional violators can conceal the intentional nature of their nonreporting of deviant behavior. Those regimes with high reporting rates that highlight nonreporting, in contrast, produce incentives for intentional violators to provide false reports, as evident in the recently revealed Russian strategy of false, rather than non-, reporting of whale catch statistics (General Accounting Office, 1992a; Yablokov, 1994; Peterson, 1993:280).

In a self-reporting context, the capacity to report is usually far less of a concern than in other-reporting and problem-reporting. Any actor always knows what behaviors it has consciously undertaken, even if it may not know what the effects of that behavior are (as discussed in problem-reporting, below). For example, governments can always report what laws and policies they have promulgated. Nor do the resources required to collect and forward such information usually prove prohibitive. Governments also usually know what actions they have taken to implement a regime. For example, states that commit resources to enforcing a regime usually also dedicate resources to tracking those efforts. Governments initially may lack the informational infrastructure to collect, analyze, and forward implementation or compliance data. Once created, however, such infrastructures develop and become embedded in bureaucratic missions and standard operating procedures (Chayes, 1972). Although governments have strong incentives not to report such information, they do know how many troops or weapons they have deployed, the degree of human rights violations they are committing, or the efforts they have or have not made to bring governmental behavior in line with environmental treaty provisions. Corporations and private actors are often even more capable than governments of reporting on their own behavior. Corporations generally have extensive management information systems to track organizational decisions, behaviors, and outputs. In short, governmental and nongovernmental actors almost always have the capacity to self-report.

Taken together, then, the supply of information to a regime that relies on self-reporting will be influenced by the extent to which the regime has both normative and behavioral support from those actors whose behavior the regime targets. High levels of transparency from self-reporting will be most likely in regimes that have strong support but do not make excessive behavioral demands on their members. To the extent that support declines or behavioral demands-and hence nonconformance-increase, we should expect to see the quality and quantity of self-reports decline. 


\section{Other-Reporting}

Regimes turn to other-reporting when dynamics and incentives within the issue area make honest self-reporting unlikely. In such regimes, the actor required to report information must gather it from other sources that often seek to conceal that information. Other-reporting may involve one government reporting on the behaviors of its own citizens, foreign governments, or foreign nationals, or it may involve nongovernmental actors reporting on behaviors of governments, or other nongovernmental actors. For example, arms proliferation regimes require information on the behavior of national weapons manufacturers as well as military departments. Trade and customs regimes require information about import and export companies as well as government trade barriers. Human rights regimes seek information on the behavior of foreign governments. Labor regimes often require information on private management and labor practices as well as government regulation of those practices. Environmental regimes seek information on the individual and corporate behaviors directly responsible for an environmental problem. Even in a nominally self-reporting context, federal governments often must report on activities of their constituent governments, such as the German Laender or American states. Like self-reporting, regime supporters will be more likely to report on others' behaviors than regime opponents. Unlike self-reporting, however, incentives to report on regime-inconsistent behavior by others depend on the degree of perceived harm from others' regime-inconsistent behaviors. The four types of otherreporters implied by these factors are illustrated in Figure 2.

\begin{tabular}{|c|c|c|}
\hline & $\begin{array}{c}\text { Supportive of Regime } \\
\text { Norms }\end{array}$ & $\begin{array}{c}\text { Opposed to Regime } \\
\text { Norms }\end{array}$ \\
\hline $\begin{array}{c}\text { Nonconformance by } \\
\text { Others Does Not Cause } \\
\text { Direct or Tangible Harm }\end{array}$ & $\begin{array}{c}\text { Regime-Minded } \\
\text { Good Citizen }\end{array}$ & $\begin{array}{c}\text { Consistent } \\
\text { Nonreporter }\end{array}$ \\
\hline $\begin{array}{c}\text { Nonconformance by } \\
\text { Others Does Cause Direct } \\
\text { or Tangible Harm }\end{array}$ & $\begin{array}{c}\text { Regime-Minded } \\
\text { Victim }\end{array}$ & $\begin{array}{c}\text { Opportunistic } \\
\text { Victim }\end{array}$ \\
\hline
\end{tabular}

FIG. 2. Actor types for other-reporting.

"Regime-minded good citizens"-actors who support regime norms but experience little direct, tangible harm from the nonconformance of others-often expend considerable resources to monitor the behavior of other actors (Puchala and Hopkins, 1983:90). Governments, corporations, NGOs, and individuals often support regimes that do not regulate them and violations of which do not directly or materially harm them. Nonetheless, precisely because they do not face the crosscutting pressures of being an information provider and a target of regulation, such actors provide a large pool of potential contributors to regime transparency. In their efforts to foster regime maintenance or development, they have incentives to monitor and report regime-inconsistent behavior, especially when such behavior does not come to light readily.

Governments have incentives to identify and report regime transgressions by others that do not inflict material harm on them if they perceive those transgressions as threatening the regime. Defending the cooperation that the regime fosters against retaliatory tit-for-tat spirals can be an important element of governmental regime-mindedness (Puchala and Hopkins, 1983). In arms control, for example, 
governments often seek to identify "militarily insignificant" violations as "early warnings" that more significant violations are afoot and thereby permit responses that will prevent the unraveling of the regime. Governments also, however, seek to avoid bringing violations to light to avoid charge-countercharge spirals and to respect the norm of diplomatic deference. These latter forces often seem to dominate, with even activist governments failing to monitor and report violations of other governments. These dynamics appear to be mitigated when the behavior of foreign nationals rather than foreign governments is involved (Trexler, 1989; Mitchell, 1994:ch. 5). Governments committed to regime goals and vulnerable to efforts to circumvent the regime have incentives to enforce rules against foreigners even more rigorously than rules against their own citizens, as evident in recent U.S. government efforts to catch smugglers violating the Montreal Protocol's ban on ozone depleting substances (Halpert, 1995). Such actions showcase a government's commitment to the regime in international and domestic fora without imposing regime compliance costs on its own citizens. Of course, only those regimes regulating behaviors that actors engage in while on foreign territory, for example, those involving international trade and shipping, present the possibility for such efforts.

Many international NGOs strongly identify with the norms of environmental and human rights regimes but often experience no direct, material harm from their violation. Amnesty International, Freedom House, Human Rights Watch, World Wide Fund for Nature (WWF), Greenpeace, and Friends of the Earth dedicate considerable resources to collecting and providing secretariats with "external and independent" information considered to facilitate assessments of compliance and effectiveness (Sachariew, 1991:34; Handl, 1992:18; Subak, 1995:14; Greene, 1993:168-9). These efforts can supplement the meager budgets of most secretariats while overcoming the diplomatic deference that makes government reporting on the behavior of other governments unlikely.

"Regime-minded victims" - those that support regime norms and also perceive themselves as materially harmed by violations-have even stronger incentives to ensure that neither their short- nor long-term interests are harmed by regime transgressions. They will be quick to frame even ambiguous behaviors that harm their short-term interests as regime-inconsistent, as doing so simultaneously strengthens existing regime rules, broadens their effective scope, and protects their short-term interests. For example, certain pollutants impose immediate and direct harms that may induce governments to monitor the behavior of their own citizens, foreign nationals, and other governments: European governments have monitored for nuclear plant accidents and chemical spills in the Rhine for years because of the immediate risks posed to valuable economic enterprises (Bernauer, 1995). Even corporate actors may have strong incentives to monitor and report on treaty-relevant behavior. Any company that chooses or is compelled to comply with a particular regulatory regime has strong incentives to monitor to ensure that their competitors are also complying. Trade regimes often rely on import/export companies to identify tariff violations.

"Opportunistic victims"- those opposed to regime norms but who experience large, material, and identifiable harms from regime violations-can be relied on to report on that nonsystematic subset of violations that harm their interests. For example, it would not be surprising to find Israel notifying the International Atomic Energy Agency if it became aware of nuclear weapons development by neighboring states, despite its ongoing unwillingness to sign the nonproliferation treaty. Likewise, despite ongoing opposition to pollution regulations, tanker captains and shipping associations have regularly provided the International Maritime Organization (IMO) with reports on governments that fail to provide reception facilities required by MARPOL (MEPC 30/Inf.30, 1990). All liability regimes rely on the transparency induced whenever an actor is aware they are being harmed and that 
the harm exceeds the costs of monitoring and responding to that harm (Bird, 1980; Cummins, Logue, Tollison, and Willett, 1975). Although regime opponents may undermine regimes by violating whenever compliance conflicts with short-term self-interest, they may strengthen regime norms by appealing to them as an additional source of legitimacy when it suits their short-term interests.

"Consistent nonreporters" will include all actors that both oppose general regime norms and are unaffected when those norms are transgressed. Holding neither a normative, principled commitment to upholding regime norms, nor an instrumental commitment that they be upheld in a specific case, they will be unlikely to contribute to regime transparency.

Unlike self-reporting, incapacity issues often prevent actors who have incentives to other-report from doing so. One major factor influencing the capacity to other-report is the ability and incentives of the actor being regulated to prevent potential reporters from observing deviant behavior. At the end of the spectrum favoring transparency, many behaviors cannot or will not be conducted clandestinely for a variety of reasons. For example, NGOs or private citizens can readily monitor whether governments pass regime-inconsistent legislation, as in the case of EU directives just mentioned. Other illicit behaviors-military invasions, deterrent weaponry, human rights violations, and excessive tariff rates-can be concealed from many actors but are always readily observable by their victims. The structure of regimes regulating coordination problems-satellite slots, airplane and ship navigation, or electro-magnetic spectra-dictates that "defection is never surreptitious cheating; it is a public attempt, made at some cost, to force the other actor into a different equilibrium outcome" (Stein, 1983:130). Other regimes regulate behaviors involving transactions in which engaging in the illicit behavior requires revealing the intent to do so to other actors, as in the buying and selling of weapons, drugs, or endangered species. As an example, the fur seal regime reversed the decline in fur seals by involving the essentially monopsonistic London fur merchants in monitoring fur seal kills (Mirovitskaya, Clark, and Purver, 1993). In other problems, transparency owes more to the practical "dominance" of detection over concealment capabilities. Activities that, by necessity, span long time periods, cover large areas, involve many people, or occur near populated areas prove difficult to conceal. Ballistic missile tests, major troop mobilizations, mining in Antarctica, or large-scale deforestation can all be readily observed. Success at hiding a proscribed behavior may also not extend to hiding its effects. The activities that produce ocean oil pollution and much land-based pollution can often be concealed but their impacts usually cannot. Whenever actors lack the incentives or practical ability to conceal their behavior and its impacts, other-reporting is always possible.

At the end of the spectrum hindering transparency, many behaviors either can be readily concealed or prove difficult to observe even when no attempt is made to conceal them. Often both the activity and impacts of ocean dumping of waste and toxic chemicals can be concealed. Similarly, chemical weapons tests (unlike nuclear tests) prove easy to conceal because of the limited temporal and spatial span of their impacts. As terrorist attacks, nuclear tests, and ocean pollution sometimes demonstrate, even clandestine activities whose impacts are observed may face the regime with "passive voice violations" in which it can only be said that the regime's rules "were violated" but not who violated them (Mitchell, 1994). In the least transparent instances, both proscribed behavior and its impacts are difficult to observe. Many international environmental problems involve behaviors that can be readily concealed and whose impacts are delayed, uncertain, or complex. Thus, those so inclined can exceed fishing quotas or release CFCs without being detected, and the impacts of such behaviors may take years to become apparent. Obtaining comprehensive data about the activities of corporations or of large numbers of individuals that occur over large areas may also prove difficult, especially if those actors are not 
already embedded in existing informational infrastructures. The sheer scale of an activity can overwhelm a government's administrative, financial, or technical capabilities, making accurate reporting difficult. International efforts to regulate weapons development, many forms of pollution, and trade in weapons, drugs, and endangered species illustrate how resource requirements may favor those seeking to conceal an activity rather than those seeking to reveal it. Developing country governments are especially likely to face capacity problems, a fact explicitly acknowledged in FCCC provisions allowing these states six times longer than developed states to provide reports and providing financial and technical assistance to prepare reports (Bodansky, 1993:545; Werksman, 1995:9; Victor and Salt, 1994:12-3).

Even when adequate resources are available, laws or norms may constrain their use. International laws and norms severely limit the authority of one government to investigate foreign governments and foreign nationals. Domestic norms and laws in many countries also constrain what information a government can collect on its citizens and, equally problematic, what information a citizen can collect on its government. Perhaps surprisingly, nongovernmental actors may have unique capacities to overcome these obstacles, as acknowledged by their involvement in the Commission on Sustainable Development (Lewis, 1992; Sessions, 1992). In human rights, transnational NGO networks often can move people and information across borders more freely than can government officials. Various wildlife groups regularly monitor and report the comings and goings of whaling vessels to the IWC and the press (Stein, 1994:178-84; Howton, 1994:191-2).

Especially when a regime seeks information on government behavior, domestic structures may have a crucial impact on whether other-reporting by substate actors occurs. As noted above, states vary in the transparency of their basic political and social institutions. While foreign governments may be constrained by norms of sovereignty and diplomatic deference, their citizens and NGOs may be constrained by factors ranging from whether the government is democratic or totalitarian, the strength of secrecy and freedom-of-information laws, the extent of political oppression, and the general openness of the political process in the state.

Actors will have incentives to report on regime-relevant behaviors of other actors in many cases, either because of their general support for regime rules or because of a more instrumental view of the regime as useful in protecting certain short-term interests. Whether other-reporting systems actually induce many actors to provide information will depend crucially on issues related to capacity. Many classes of behavior are inherently or practically difficult to conceal but many other classes of behavior are not. The capacity for other-reporting will also be influenced by the legal rights an actor has to collect information about the other.

\section{Problem-Reporting}

The difficulties of self- and other-reporting lead many regimes, especially environmental ones, to focus information systems on the state of a problem, often one that is influenced by factors other than human behavior. Regimes often seek information on trends in such problems and on how human behaviors affect these trends. Statisticians and scientists employed by intergovernmental agencies, governments, nongovernmental organizations, or universities often have strong independent incentives to collect systematic data on levels and trends in economic indicators, disease rates, weather patterns, or environmental degradation. Other actors may observe more anecdotal evidence of trends in particular problem areas. Regimes that desire reports on the status of a problem avoid the disincentives posed by fears of self-incrimination in the case of self-reporting or fears of retribution in the case of other-reporting. However, such regimes often must create strong positive incentives to monitor such problems, especially when monitoring is difficult or expensive. 
Any institutions-whether governmental, intergovernmental, or nongovernmental-or individuals that support regime goals will have incentives to monitor and report on trends in the problems the regime seeks to resolve. Driven by a belief that a problem or potential problem exists, such actors will be especially likely to monitor the problem if they perceive inadequate collective action as driven by insufficient information regarding the causes of and solutions to the problem. Many environmental regimes initially focus on gathering information on the problem rather than regulating behavior. Actors will have especially strong incentives to contribute information to such regimes if the regime's collective information would be impossible or prohibitively expensive to collect individually. For example, accurate understanding of the sources of European acid precipitation required aggregating otherwise-unavailable scientific data from several states (Levy, 1993).

Problem characteristics influence incentives for monitoring and reporting. These incentives will be greater with problems that threaten harms that are larger, more likely, more temporally or spatially proximate, or are growing rapidly or approaching critical levels. Thus, environmental problems that have domestic as well as global impacts, for example, smog and acid precipitation, can be expected to receive more attention than others. Similarly, as a health problem approaches epidemic levels, as an environmental resource approaches its carrying capacity, or as a species nears extinction, actors concerned or threatened by such developments will have increasing incentives to contribute to problem-reporting systems.

In countries whose governments oppose resolution of particular health or environmental problems, academic or independent scientists or analysts may nonetheless investigate such problems. The inherent scientific interest of a problem or its instrumental value in enhancing a scientist's links and stature within an international epistemic community can encourage monitoring and reporting (Levy, 1993; Haas, 1989). Economically motivated actors invest resources in identifying future threats to their economic interests. For example, even without governmental programs, corporations with water intakes on a polluted river could be expected to monitor water quality to protect equipment from upstream pollution. Although unlikely, even actors opposed to a regime may monitor trends in an environmental resource, for example, if they believe they may thereby demonstrate that a problem no longer exists and hence regulation is no longer needed.

The capacity to monitor and report on a given problem depends on the type of information desired and the resources and technologies available to collect it. Many health, meteorological, or environmental problems can be monitored through existing technologies readily available to most governments. Other problems may require more expensive or exotic technologies-for example, remote satellite sensing - that many governments either cannot afford or do not have access to, or that are deemed too expensive for dedication to such problems (Hönsch, 1992; Litfin, 1995). Transnational epistemic communities of scientists often collectively conduct research at a scale and range that overcomes such constraints (Haas, 1990). In the environmental sphere, NGOs often contribute to such enterprises, but usually lack the financial resources to make wide-scale, systematic contributions to monitoring other than by repackaging other institutions' data (Sachariew, 1991:39; Tietenberg and Victor, 1994:29).

\section{Strategies for Increasing Transparency}

The foregoing sections have delineated how a regime's level of transparency is constrained by actors' incentives and capacities, characteristics of the issue area being regulated, and other exogenous factors. Such factors, however, underdetermine regime transparency. Consider regimes in which the supply of transparency falls short of their demand for transparency. Such regimes can adopt strategies to 
increase self-, other-, and problem-reporting and thereby increase transparency. Incentives, capacity, and even problem structure are not exclusively exogenous factors beyond regime influence.

Regime policies can increase the likelihood of reporting by enhancing incentives for reporting while reducing the incentives for not reporting. The former entails identifying and facilitating the goals of potential reporting agents. The actors most likely to report in all three informational systems are those committed to regime norms. Encouraging reporting requires that the regime convince these potential reporters that the information they provide will be processed, analyzed, and disseminated in ways that foster regime goals, is crucial to that enterprise, and will provide direct benefits to the information provider (Sand, 1992:14). In self-reporting systems, even "committed compliers" will fail to report if they lack a sense that reporting is crucial to regime success. Often this requires that the regime create-and provide reporters with access to-collective information that is more valuable than national data already available. Thus, the regular, even if sometimes inaccurate, reporting by many states in the acid rain, whaling, and many fishery regimes reflects each regime's ability to aggregate individual reports into collective data that no state alone could produce (General Accounting Office, 1992a; Levy, 1993). By immediately processing daily reports on ship inspections, the European maritime enforcement regime provides otherwise unavailable information that allows national inspectorates to deploy inspectors more efficiently against those ships most likely to be violating international maritime rules (Kasoulides, 1990). Regimes can stress reporting's importance and increase its frequency by discussing reported information, and even black-listing those that fail to report on time, as in the ILO, CITES, or the IWC (Landy, 1966; Sand, 1992:14; Caldwell and Corrigan, 1991; Sachariew, 1991:43).

Whether involving self- or problem-reporting, leader states that provide highquality reports can create a context that makes reporting appear important, as evident in current U.S. reporting in the FCCC (Victor and Salt, 1994:12). Unfortunately, secretariats often reinforce tendencies toward not reporting by merely collating and distributing national reports at meetings of the parties, rather than providing the analysis and discussion that would highlight the importance of accurate self-reporting (Sachariew, 1991:47; Mitchell, 1994:134-5). In the case of other-reporting, actors often report noncompliance to evoke assistance in sanctioning by other regime members. Accomplishing this requires that the regime credibly demonstrate that such reports produce the desired sanctions, somehow overcoming the oft-cited obstacles to sanctioning that make international collective sanctions rare (Sachariew, 1991:41; Axelrod and Keohane, 1986).

Regimes can also adopt facilitative approaches that essentially reward reporting, rather than sanctioning self-reported behavioral shortfalls. Regular self-reporting, and allowing access to otherwise sensitive information, can become a precondition for receiving technical assistance and advice, as in the FCCC, LRTAP, and Montreal Protocol noncompliance procedures (UN/ECE, 1994:133; Bodansky, 1993:548). Governments and corporate actors often use annual conferences to unveil new policies that demonstrate their commitment to regime goals, or their "exemplary records" of past compliance and enforcement. "White lists" provide strong incentives to report, as evident in the voluntary corporate self-reporting of environmental audits, eco-labeling, and ISO standards (Salzhauer, 1991; Anonymous, 1991; Sand, 1990:26). Inducing self-reporting requires that reports must "not be seen as an effort to 'mobilize shame,' but rather as an attempt to "mobilize aid for compliance"" (General Accounting Office, 1992b:8). Such selective incentives can induce reporting even by actors lacking normative commitments to regime goals.

Regimes must also remove disincentives to reporting. Regimes relying on self-reporting must forego adversarial responses to self-reported information. Noncon- 
formers (whether intentional or good faith) will not provide honest self-reports if they believe that doing so will lead to punishment. Many regimes, recognizing that compliance-oriented approaches often make information less available, develop an effectiveness-oriented approach of aggregating self-reports across actors in public documents to preclude informal sanctioning by publics, the media, and NGOs. Several states opposed FCCC reporting requirements until they mandated that the secretariat aggregate information claimed as confidential before releasing it (Bodansky, 1993:545). Private, especially corporate, actors may not self-report from fear that proprietary, confidential information will be released. Private actors may not other-report from fear of reprisals by those they identify as noncompliers, a concern vividly illustrated in human rights regimes. ${ }^{7}$ Facilitating reporting requires that a regime address these concerns.

Regimes can increase the capacity for reporting as well as the incentives for it. As already noted, capacity issues are usually not at issue in self-reporting. In the case of other-reporting, however, how a regime frames its substantive rules influences the capacity to monitor and report. For example, many regimes establish complete bans-of atmospheric nuclear testing, whaling, or elephant poaching - in part because they are easier to monitor than non-zero numerical limits (Barbier, 1995). Indeed, in the whaling regime, NGOs have used DNA sampling to reveal Japanese violations of bans on killing of protected species, but have rarely attempted to monitor whether Japanese whalers have exceeded scientific quotas (Baker and Palumbi, 1994). Regimes also can frame rules so that the line between permitted and outlawed behavior coincides with the technical and financial limits of current monitoring capability (Grubb, 1993). MARPOL negotiators replaced initial limits on oil discharges, which existing equipment could not monitor, with a ban on all discharges that left a "visible sheen" (IMO, 1985, MARPOL Annex I, Regulation 9). Similarly, the Threshold Test-Ban Treaty outlawed underground tests that leaked radiation beyond the testing country's border, at least in part because only in such cases could other countries even conceivably identify the violation. Regimes often increase "monitorability" by regulating the most transparent acts in the series leading up to some undesirable behavior (Tietenberg and Victor, 1994:25; Fischer, di Primio, and Stein, 1990). MARPOL supplemented discharge limits with equipment requirements because the latter were more likely to come to light. Even though international trade is only one of several forces endangering various species, governments could more readily monitor trade in, rather than killing of, endangered species.

Many regimes increase transparency by removing legal and practical barriers to monitoring and reporting. Behaviors that can be observed without the monitored actor's cooperation tend to be implicitly authorized. In other cases, regimes can establish new legal rights and obligations. Arms control agreements bar states from actions that would prevent satellite and aerial surveillance, and establish rights to baseline data verification and on-site inspections. Environmental regimes have established the right to place international observers on whaling ships (Birnie, 1985), to inspect ships in port states (Mitchell, 1994), and to conduct on-site inspections of wetlands degradation (Ramsar Convention Bureau, 1990). Regimes also grant nongovernmental actors the right to introduce information regarding violations to the regime, as evident in the legal standing of European Union citizens to identify governmental violations of EU directives, and the right of NGOs to bring human rights and environmental violations to the cognizant secretariat. Some

\footnotetext{
7 Of course, regimes must balance the value of anonymity as an inducement to reporting against the concomitant reduction in accountability and, hence, reliability of the reports provided.
} 
regimes give secretariats a mandate to make inquiries of governments, or conduct independent investigations and on-site inspections which, though intrusive, may prove more politically acceptable than such inspections conducted by other countries (Kunzendorff, 1989:35-6; Kellman, 1995:10-2; Boyle, 1991:236). Various regimes, including the United Nations Environment Program, the World Meteorological Organization, and the LRTAP and MedPlan secretariats, directly collect data themselves, coordinate the research and monitoring efforts of other actors, establish guidelines for compatible methodologies, increase the technical or financial capacity to monitor and report, or aggregate and focus monitoring efforts (Victor and Salt, 1994:11; Thacher, 1991:41; Haas, 1995:32; Sachariew, 1991:38; Levy, 1993).

At the simplest level, regimes can enhance reporting capacity by minimizing practical obstacles to reporting and by providing simple and clear report formats (Peet, 1992). The computerized self-reporting incorporated in regional maritime enforcement regimes has induced states otherwise not reporting to provide regular and detailed enforcement data (Kasoulides, 1990; Mitchell, 1994:ch. 4). Successful reporting systems also work with, rather than against, the pressures faced by reporting bureaucracies or agents. Bureaucratic dynamics may lead infrequent annual reporting requirements to be forgotten or deemed unimportant, while leading daily or weekly reporting requirements to be incorporated into standard operating procedures (Mitchell, 1994:140).

\section{Conclusion}

Structural, exogenous factors and regime-manipulable, endogenous factors influence a regime's ability to create the transparency deemed important to producing and evaluating regime effectiveness. A regime's level of transparency reflects the adequacy of the supply of information relative to the regime's demand for information. A regime's demand for information varies depending on how the information will be used: "compliance-oriented" transparency systems seek information to prompt responses to individual actors not fulfilling regime obligations as a means of fostering regime success, while "effectiveness-oriented" transparency systems seek to assess collective progress toward regime goals. A regime's supply of information varies depending on the type of regime information system involved, namely, self-reporting, other-reporting, or problem-reporting. The incentives and capabilities of any actor to provide information vary across these systems. Exogenous determinants of incentives and capacities impose constraints on the transparency to which a given regime can aspire. These include the commitment actors have to regime norms, the degree to which their behavior conforms to those norms, and the degree to which they are harmed by the behavioral nonconformance of others. Especially in the case of other-reporting, the structure of the problem being addressed will have a large influence on the transparency achieved. Higher levels of transparency may reflect merely simpler tasks: regimes involving coordination problems such as satellite slot or electro-magnetic spectrum allocation will exhibit significant transparency even with a poorly designed regime; regimes involving easily hidden behaviors such as human rights violations or weapons development will exhibit less transparency even with a well-designed regime.

Although these structural, exogenous factors influence the transparency a regime will achieve, they underdetermine it. The design of regime information systems can, to a degree, influence the incentives and capacity to provide information. Indeed, regime information systems will induce the greatest transparency when designed in response to, rather than imposed on, the different contexts, and corresponding constraints, they face. Successful regimes create or enhance the incentives, abilities, or legal authority of various actors to contribute to regime transparency. Regimes can foster transparency by increasing the incentives for reporting, decreasing the 
often-strong incentives for nonreporting, and enhancing the capacity to monitor and report. These efforts include demonstrating that reporting furthers the goals of the regime and of the actor reporting, reducing the likelihood that an actor will face sanctions for revealing its own illicit behavior or reprisals for revealing such behavior by others, and enhancing the "monitorability" of the regime either by framing regime prescriptions to coincide with existing monitoring capabilities or by directly enhancing those capabilities.

Scholars and practitioners have frequently cited the value of transparency: regime success allegedly requires consistent, high-quality information on regime-related behavior and conditions. If we accept these assertions that transparency fosters regime compliance and effectiveness, then identifying the conditions and policies that make transparency possible becomes crucial. The arguments here have been developed deductively and illustrated with empirical, if anecdotal, examples. More systematic efforts need to be made to identify and test whether the factors identified here or other, quite different, factors cause regimes to achieve or fail to achieve transparency. Improving our understanding of the sources of transparency will help answer theoretical and empirical questions of why some regimes do better than others, but will also help answer practical questions of how we can help regime practitioners increase both regime compliance and regime effectiveness.

\section{References}

Аввотт, K. (1993) "Trust but Verify": The Production of Information in Arms Controls Treaties and Other International Agreements. Cornell International Law Journal 26 (Winter): 1-58.

Alston, P., ED. (1992) The United Nations and Human Rights: A Critical Appraisal. Oxford: Oxford University Press.

Andresen, S., And J. Wettestad (1995) International Problem-solving Effectiveness: The Oslo Project Story So Far. International Environmental Affairs 7(Spring): 127.

Anonymous (1991) Will None but the Greatest Qualify for Europe's Ecolabel? New Scientist 129(23 March): 18-19.

Ausubel, J., AND D. Victor (1992) Verification of International Environmental Agreements. Annual Review of Energy and the Environment 17(1):1-43.

Axelrod, R., And R. O. Keohane (1986) "Achieving Cooperation Under Anarchy: Strategies and Institutions.” In Cooperation Under Anarchy, edited by K. Oye, pp. 226-254. Princeton, NJ: Princeton University Press.

Baker, C. S., And S. R. Palumbi (1994) Which Whales Are Hunted? A Molecular Genetic Approach to Monitoring Whaling. Science 265(9 September):1538-1539.

BARbier, E. B. (1995) Elephant Ivory and Tropical Timber: The Role of Trade Interventions in Sustainable Management. Journal of Environment and Development 4(Summer): 1-32.

Bernauer, T. (1995) The International Financing of Environmental Protection: Lessons from Efforts to Protect the River Rhine Against Chloride Pollution. Environmental Politics 4(Fall):369-390.

Bird, P. J. W. N. (1980) Environmental Policy Making: Liability for Externalities in the Presence of Transaction Costs. Natural Resources Journal 20(July):487-499.

BIRNIE, P. (1985) International Regulation of Whaling: From Conservation of Whaling to Conservation of Whales and Regulation of Whale-watching. New York: Oceana.

Birnie, P. W., AND A. E. Boyle (1992) International Law and the Environment. Oxford: Oxford University Press.

BodAnsky, D. (1993) “Managing Climate Change.” In Yearbook of International Environmental Law, edited by G. Handl, pp. 60-74. London: Graham and Trotman.

Boyle, A. E. (1991) Saving the World? Implementation and Enforcement of International Environmental Law Through International Institutions. Journal of Environmental Law 3(2):229-245.

CALDwELl, J., AND H. CORRIGAN (1991) The Implementation of CITES in 1988 and 1989 as Demonstrated by the Annual Reports Submitted by the Parties. A Report prepared for the CITES Secretariat-CITES/Doc.8.17(Rev.)Annex. Cambridge: World Conservation Monitoring Centre.

Chayes, A. (1972) An Inquiry into the Workings of Arms Control Agreements. Harvard Law Review 85(March):905-969. 
Chayes, A. (1991) Managing the Transition to a Global Warming Regime or What to Do Till the Treaty Comes. Foreign Policy 82(Spring).

Chayes, A., And A. H. Chayes (1995) The New Sovereignty: Compliance with International Regulatory Agreements. Cambridge, MA: Harvard University Press.

Collins, K., AND D. EARnSHAw (1993) "The Implementation and Enforcement of European Community Environment Legislation.” In A Green Dimension for the European Community: Political Issues and Processes, edited by D. Judge, pp. 213-249. Portland, OR: Cass.

Cummins, P. A., D. E. Logue, R. D. Tollison, And T. D. Willett (1975) Oil Tanker Pollution Control: Design Criteria Vs. Effective Liability Assessment. Journal of Maritime Law and Commerce 7(October): 169 .

DeSombre, E. (1995) Baptists and Bootleggers for the Environment: The Origins of United States Unilateral Sanctions. Journal of Environment and Development 4(Winter):53-76.

Downs, G. W., D. M. Rocke, And P. N. Barsoom (1996) Is the Good News About Compliance Good News About Cooperation? International Organization 50(3) (Summer):379-406.

Fischer, W. (1991) "The Verification of a Greenhouse Gas Convention-A New Task for International Politics?” In Verification Report, 1991, edited by J. B. Poole, pp. 197-206. London: VERTIC.

Fischer, W. (1992) "Verification of International Treaties for the Protection of the Environment-Some Empirical Evidence." In A Regime to Control Greenhouse Gases: Issues of Verification, Monitoring, Institutions. Proceedings of a Workshop, Bad Neuenahr, June 12-14, 1991, edited by J. C. di Primio and G. Stein, pp. 47-52. Julich, Germany: Forschungszentrum Julich GmbH.

Fischer, W., J. C. Di Primio, And G. Stein (1990) A Convention on Greenhouse Gases: Towards the Design of a Verification System. Julich, Germany: Forschungszentrum Julich GmbH.

Florini, A. M. (1995) Forces of Evolution in International Relations: The Case of Transparency. Paper presented at the Annual Meeting of the International Studies Association, Chicago.

General Accounting Office (1992a) International Environment: International Agreements Are Not Well Monitored. GAO/RCED-92-43. Washington, DC: Government Printing Office.

General Accounting OfFice (1992b) International Environment: Strengthening the Implementation of Environmental Agreements. GAO/RCED-92-188. Washington, DC: Government Printing Office.

Greene, O. (1993) International Environmental Regimes: Verification and Implementation Review. Environmental Politics 2(Winter): 156-173.

Greene, O. (1994) On Verifiability, and How It Could Matter for International Environmental Agreements. IIASA Working Paper WP-94-116. Laxenburg, Austria: IIASA.

Grubb, M. (1993) Tradeable Permits and the Comprehensive Approach to Climate Change: Can We Get the Best of Both Worlds? Natural Resources Forum 17(1):51-58.

HaAs, P. M. (1989) Do Regimes Matter? Epistemic Communities and Mediterranean Pollution Control. International Organization 43(Summer):377-403.

HaAs, P. M. (1990) Saving the Mediterranean: The Politics of International Environmental Cooperation. New York: Columbia University Press.

HaAs, P. M. (1993) "Protecting the Baltic and North Seas." In Institutions for the Earth: Sources of Effective International Environmental Protection, edited by P. Haas, R. O. Keohane, and M. Levy, pp. 133-182. Cambridge, MA: MIT Press.

HaAs, P. M. (1995) “Global Environmental Governance." In Issues in Global Governance, edited by the Commission on Global Governance, pp. 333-370. Boston: Nijhoff.

Halpert, J. E. (1995) “Freon Smugglers Find Big Market.” New York Times, April 30, p. A1.

HANDL, G. (1992) "Environmental Security and Global Change: The Challenge to International Law." In Yearbook of International Environmental Law, edited by G. Handl, pp. 3-33. London: Graham and Trotman.

Hönsch, H. (1992) "Remote Sensing Satellite Data as an Instrument to Verify a Greenhouse Gas Convention-A Case Study in the Brazilian Amazon.” In A Regime to Control Greenhouse Gases: Issues of Verification, Monitoring, Institutions. Proceedings of a Workshop, Bad Neuenahr, June 12-14, 1991, edited by J. C. di Primio and G. Stein, pp. 155-166. Julich, Germany: Forschungszentrum Julich GmbH.

Howton, M. (1994) International Regulation of Commercial Whaling: The Consequences of Norway's Decision to Hunt the Minke Whale. Hastings International and Comparative Law Review 18(Fall): 175-193.

Hufbauer, G. C., And J. J. Schott (1985) Economic Sanctions Reconsidered: History and Current Policy. Washington, DC: Institute for International Economics.

Huibers, H. E. (1991) "Statement to the Seminar on Port State Control." Annex 10. In Report on the Joint IMIF/MOU Seminar on Port State Control. Southampton, U.K., March 21, 1991. London: International Maritime Industries Forum. 
IMO (1985) Regulations for the Prevention of Pollution by Oil. Articles of the International Convention for the Prevention of Pollution from Ships, 1973, and of the Protocol of 1978 Relating Thereto. Annex I of MARPOL 73/78 Including Proposed Amendments and Unified Interpretation of the Provisions of Annex I. London: International Maritime Organization.

IMO/LC.2/CIRC.318 (1993) Reporting on Activities Related to Waste Disposal and Incineration at Sea. London: International Maritime Organization.

Kasoulides, G. (1990) Paris Memorandum of Understanding: A Regional Regime of Enforcement. International Journal of Estuarine and Coastal Law 5(February):180-192.

Katscher, W., G. Stein, J. Lanchbery, And J. Salt, eds. (1994) Greenhouse Gas Verification: Why, How and How Much? Proceedings of a Conference. Julich, Germany: KFA Forschungszentrum Julich GmbH.

Kellman, B. (1995) The Chemical Weapons Convention: A Verification and Enforcement Model for International Environmental Treaties. Paper presented at the Annual Meeting of the International Studies Association, Chicago.

KIM, C. J. (1994) Moving Targets and Corrals: Managing Compliance with International Commitments. Law Thesis, Harvard University, Cambridge, Mass.

Kimball, L. A. (1992) Forging International Agreement: Strengthening Inter-governmental Institutions for Environment and Development. Washington, DC: World Resources Institute.

Krasner, S. D. (1991) Global Communications and National Power: Life on the Pareto Frontier. World Politics 43(April):336-366.

Kunzendorff, V. (1989) Verification in Conventional Arms Control. Adelphi Papers No. 245. London: Brassey's for the International Institute for Strategic Studies.

Landy, E. A. (1966) The Effectiveness of International Supervision: Thirty Years of I.L.O. Experience. London: Stevens and Son.

LANG, W. (1991) Is the Ozone Depletion Regime a Model for an Emerging Regime on Global Warming? Journal of Environmental Law 9:161-174.

Levy, M. (1993) "European Acid Rain: The Power of Tote-board Diplomacy." In Institutions for the Earth: Sources of Effective International Environmental Protection, edited by P. Haas, R. O. Keohane, and M. Levy, pp. 75-132. Cambridge, MA: MIT Press.

Levy, M. A., O. R. Young, AND M. ZüRn (1995) The Study of International Regimes. European Journal of International Relations 3(1):267-330.

Lewis, P. (1992) "Delegates at Earth Summit Plan a Watchdog Agency.” New York Times, June 7, p. 20.

LindLey, D. (1996) Transparency and Security Regimes: A Study of the Concert of Europe and the United Nations. Paper presented at the CSIA Library, Harvard University, Cambridge, Mass.

Litfin, K. T. (1995) A Watched Planet Never Boils? An Inquiry into Global Environmental Monitoring. Paper presented at the Annual Meeting of the International Studies Association, Chicago.

MEPC 30/INF.30 (1990) Questionnaire on the Adequacy of Facilities in Ports for the Reception of Oil Residues from Ships: Summary of Replies. International Chamber of Shipping. London: International Maritime Organization.

Mirovitskaya, N., M. Clark, And R. G. Purver (1993) "North Pacific Fur Seals: Regime Formation as a Means of Resolving Conflict.” In Polar Politics, edited by O. R. Young and G. Osherenko, pp. 22-55. Ithaca, NY: Cornell University Press.

Mrtchell, R. B. (1994) Intentional Oil Pollution at Sea: Environmental Policy and Treaty Compliance. Cambridge, MA: MIT Press.

Mitchell, R. B. (1996) Strategies of International Social Control: Changing Incentives, Opportunities, or Values. Paper presented at the Annual Meeting of the International Studies Association, San Diego, Calif.

Mueller, H. (1994) Transparency in Nuclear Arms: Toward a Nuclear Weapons Register. Arms Control Today 24 (October):3(5).

O'Flaherty, M. (1994) The Reporting Obligation Under Article 40 of the International Covenant on Civil and Political Rights: Lessons to Be Learned from Consideration by the Human Rights Committee of Ireland's First Report. Human Rights Quarterly 16(3):515.

Oye, K. A. (1986) "Explaining Cooperation Under Anarchy: Hypotheses and Strategies." In Cooperation Under Anarchy, edited by K. Oye, pp. 1-24. Princeton, NJ: Princeton University Press.

PeEt, G. (1992) Operational Discharges from Ships: An Evaluation of the Application of the Discharge Provisions of the MARPOL Convention by Its Contracting Parties. Available as MEPC 32/Inf.8 (16 January 1992). Amsterdam: AIDEnvironment.

Peterson, M. J. (1993) “International Fisheries Management.” In Institutions for the Earth: Sources of Effective International Environmental Protection, edited by P. Haas, R. O. Keohane, and M. Levy, pp. 249-308. Cambridge, MA: MIT Press. 
Puchala, D., And R. Hopkins (1983) "International Regimes: Lessons from Inductive Analysis." In International Regimes, edited by S. D. Krasner, pp. 61-91. Ithaca, NY: Cornell University Press.

Qureshi, A. H. (1990) The New GATT Trade Policy Review Mechanism: An Exercise in Transparency or "enforcement"? Journal of World Trade 24(June):147-160.

Ramsar Convention Bureau (1990) Summary Report on the Operation of the Ramsar Bureau's Monitoring Procedure 1988-1989. Gland, Switzerland: Ramsar Convention Bureau.

SACHARIEW, K. (1991) "Promoting Compliance with International Environmental Legal Standards: Reflections on Monitoring and Reporting Mechanisms." In Yearbook of International Environmental Law, edited by G. Handl, pp. 31-52. London: Graham and Trotman.

Salzhauer, A. L. (1991) Obstacles and Opportunities for a Consumer Ecolabel. Environment 33(November):10-21.

SAND, P. H. (1990) Lessons Learned in Global Environmental Governance. Washington, DC: World Resources Institute.

SAND, P. H., ED. (1992) The Effectiveness of International Environmental Agreements: A Survey of Existing Legal Instruments. Cambridge: Grotius.

SANDS, P. (1993) Enforcing Environmental Security: The Challenges of Compliance with International Obligations. Journal of International Affairs 46(Winter):367-390.

Secretariat of the Memorandum of Understanding on Port State Control (1992) Annual Report, 1992. The Hague: The Netherlands Government Printing Office.

Sessions, K. G. (1992) Institutionalizing the Earth Summit: The United Nations Commission on Sustainable Development. UNA-USA Occasional Paper No. 7. New York: United Nations Association of the USA.

Stein, A. A. (1983) "Coordination and Collaboration: Regimes in an Anarchic World." In International Regimes, edited by S. D. Krasner, pp. 115-140. Ithaca, NY: Cornell University Press.

Stein, C. M. (1994) Whales Swim for Their Lives as Captain Ahab Returns in a Norwegian Uniform: An Analysis of Norway's Decision to Resume Commercial Whaling. Temple International and Comparative Law Journal 8(Spring):155-185.

SubaK, S. (1995) Verifying Compliance with an Unmonitorable Climate Convention. Unpublished paper. Norwich, England.

Thacher, P. S. (1991) "Focusing on the Near Term: Alternative Legal and Institutional Approaches to Global Change.” In Greenhouse Warming: Negotiating a Global Regime, edited by J. T. Mathews, pp. 37-60. Washington, DC: World Resources Institute.

Tietenberg, T., AND D. G. Victor (1994) Administrative Structures and Procedures for Implementing a Tradable Entitlement Approach to Controlling Global Warming. Paper prepared for the UN Conference on Trade and Development, Laxenburg, Austria: IIASA.

Trexler, M. C. (1989) The Convention on International Trade in Endangered Species of Wild Fauna and Flora: Political or Conservation Success? Ph.D. Thesis, University of California, Berkeley. Berkeley, Calif.

UN/ECE (1994) "Compliance and Sulphur Protocol." Note Based in Discussions at a Consultation Convened by the Bureau of the Executive Body, Geneva, March 1, 1993. Environmental Policy and Law 24(April/June):132-133.

UNEP/OzL.Pro.4/6 (1992) The Reporting of Data by the Parties to the Montreal Protocol on Substances That Deplete the Ozone Layer. Nairobi: United Nations Environment Programme.

United Nations, and Intergovernmental Negotiating Committee (1992) United Nations Framework Convention on Climate Change. A/AC.237/18 (Part II)/Add.1. New York: United Nations.

Victor, D. (1994) Review Mechanisms in the Effective Implementation of International Environmental Agreements. IIASA Working Paper WP-94-114. O. Greene, J. Lanchbery, J. C. di Primio, and A. Korula. Laxenburg, Austria: IIASA.

Victor, D. G., AND J. E. SAlt (1994) From Rio to Berlin: Managing Climate Change. Environment 36(December):6-15, 25-32.

WALtZ, K. (1979) Theory of International Politics. New York: McGraw-Hill.

Werksman, J. (1995) "Designing a Compliance System for the UN Framework Convention on Climate Change." In Improving Compliance with International Environmental Law, edited by J. Cameron, J. Werksman, and P. Roderick, pp. 85-112. London: EarthScan.

YABlokov, A. V. (1994) Validity of Whaling Data. Nature 367(13 January): 108.

YounG, O. (1991) "The Effectiveness of International Institutions: Hard Cases and Critical Variables." In Governance Without Government: Change and Order in World Politics, edited by J. N. Rosenau and E.-O. Czempiel, pp. 160-194. New York: Cambridge University Press. 